Bernal (Great Britain), on (1) X-ray analysis of materials, and (2) the structure of proteins; Prof. $K$. Bratanov (Bulgaria), on the application of vegetative and sexual hybridization in stock-breeding; Dr. M. Degerbøl (Denmark), on prehistory and zoology ; Prof. E. Grillot (France), on luminescence of crystalline minerals ; Acad. L. Infeld (Poland), on the influence of Copernicus on the development of physics; Prof. Y. Le Grand (France), on recent researches on optical physiology; Acad. V. P. Nikitin (U.S.S.R.), on electrical welding ; Sir Robert Watson-Watt (Great Britain), on the education of scientific workers; Dr. W. A. Wooster (Great Britain), on diffuse $\mathrm{X}$-ray reflexions and the physical properties of crystals.

Excursions were arranged for the delegates to various centres of interest, in particular to the new steel town of Stalinvaros, to the ancient royal seat of Vesperen, to the district surrounding Lake Balaton and to a collective farm. Receptions were given by the Hungarian Academy of Sciences and by various delegations. Visits to the opera and ballet were also arranged. Just before the last session of the Assembly, a concert was given by the following distinguished musicians: Annie Fischer, Alexander Svéd, Ede Zathureczky, Mihaly Szèkely and Maria Gyurkovits. The hospitality extended to the guests was truly magnificent and they will long remember their stay on the island Margitszigit in the Danube.

Prof. F. Joliot-Curie (France) was re-elected president. Other officers re-elected included Prof. J. D. Bernal, Prof. C. F. Powell (vice-presidents), Dr. W. A. Wooster (treasurer), and Dr. E. G. Edwards (honorary secretary). The total membership of the scientific and technical organizations affiliated to the Federation has risen from 44,000 in 1951 to 136,770 in 1953, and it is distributed over thirteen countries.

W. A. Wooster

\section{SYMPOSIUM ON GEOCHEMISTRY AT ZURICH}

A

SYMPOSIUM fon geochemistry was held in Zurich during August 11-13 under the auspices of the International Union of Chemistry. It was presided over by Dr. M. Fleischer and by the local chairman, Prof. C. Burri, with Prof. T. F. W. Barth acting as secretary. More than sixty members, representing eighteen countries, were present. This meeting was the first international gathering of geochemists.

The material read at the symposium was divided into two groups: (1) reports relating to the problem of organizing, completing and making available geochemical data; (2) papers on geochemistry and allied subjects. The first group of communications included the following reports : by M. Fleischer on the geochemical work of the Geochemistry and Petrology Branch of the U.S. Geological Survey and on the progress of the revision of Clarke's "Data of Geochemistry" (Bull. 770, U.S. Geol. Surv.); by Marjorie Hooker on the progress made in the revision of Washington's "Chemical Analyses of Igneous Rocks" (Prof. Pap. 99, U.S. Geol. Surv.) ; by W. Müller on the geochemical work of Gmelin Institute; by $P$. Rosbaud on the publication of geochemical papers in Geochimica and Cosmochimica Acta (Pergamon Press, London); by K. Rankama on the compilation, revision and organization of current geochemical work; and by 'T. F'. W. Barth on current geochemical research throughout the world. The second group comprised some twenty-five papers dealing with a variety of subjects, such as the geochemistry of certain elements, the distribution and abundance of elements in ground water, sea water, sedimentary and igneous rocks, the association of uranium with mineral hydrocarbons, the uranium content of deep-sea sediments, the geochemistry of petroleum and allied substances, the minerals of pegmatites, the composition and origin of meteorites, petrochemistry and petrogenesis, and the use of the periodic system of geochemistry. A fuller report of this meeting will be published in Geochimica and Cosmochimica Acta.

The meeting took place in the Mineralogical and Petrographical Institute of the Federal Technical College in Zurich by invitation of Prof. C. Burri and with the assistance of the staff of the Institute. After the meeting, a group of members of the symposium took part in an excursion to the Eastern Gotthard Massif (August 14-15), led by Prof. C. Burri.

During the symposium six members of the Commission on Geochemical Localization of the Elements of the International Union of Chemistry, who were present, met and, among other business, elected Prof. H. C. Urey as a member of the Commission in succession to the late Prof. P. Niggli, and Prof. C. Burri as an observer attached to the Commission. The composition of the Commission (subject to confirmation by the Committee of the International Union of Chemistry) is as follows: M. Fleischer (Washington), president; T. F. W. Barth (Oslo), vice-president; K. Rankama (Helsinki), secretary; and members, H. S. Brown (Pasadena), C. W. Correns (Göttingen), D. Guimaraes (Belo Horizonte), A. Holmes (Edinburgh), E. Raguin (Paris), S. I. Tomkeieff (Newcastle upon Tyne) and H. C. Urey (Chicago).

\section{EFFECTS OF ATMOSPHERIC POLLUTION ON VEGETATION}

$\mathrm{O}$ $\mathrm{N}$ September 9, the last day of the Liverpool meeting, Sections K (Botany) and K* (Forestry) of the British Association jointly discussed the increasingly important topic of the deleterious effects of chemical substances in the atmosphere on plant growth. It is all too well known that soot and gaseous products of combustion, such as sulphur dioxide, when released into the air over and around large cities and industrial areas, not only cause damage to buildings but also impair the health of animals and human beings. The damage to vegetation due to the same causes is less widely known but is very familiar to those who have to cultivate plants in forest, field, gar. den or glasshouse where atmospheric pollution occurs. In Great Britain the damage to glasshouse plants was especially noticeable during the unusually severe fogs that occurred during the winter of 1952-53. That the problem is not confined to Great Britain is shown by catastrophes such as those which occurred in the Meuse valley in Belgium in 1930, at Donora in Pennsylvania in 1948 and at Poza Rica in Mexico in 1950, in all of which localities much human illness and numerous deaths were shown to be due directly to short periods during which the atmosphere was more highly polluted than usual. A large-scale investigation of the damage to vegetation caused by 